Notes and Comments

\title{
Edessa meditabunda (Hemiptera: Pentatomidae) feeding on Physalis peruviana (Solanaceae) in the highlands of Brazil
}

\author{
M. A. Soares ${ }^{a *}$ (D), W. Faustino-Júnior ${ }^{\mathrm{a}}$ (D), B. M. C. Castro ${ }^{\mathrm{b}}$ (D), J. A. M. Fernandes ${ }^{\mathrm{c}}$ (D), G. L. D. Leite ${ }^{\mathrm{d}}$ (D) and J. C. Zanuncio a $^{\mathrm{b}}$ \\ aUniversidade Federal dos Vales do Jequitinhonha e Mucuri - UFVJM, Departamento de Agronomia, Diamantina, MG, Brasil \\ bUniversidade Federal de Viçosa - UFV, Departamento de Entomologia/BIOAGRO, Viçosa, MG, Brasil \\ 'Universidade Federal do Pará - UFPA, Departamento de Biologia, Belém, PA, Brasil \\ dUniversidade Federal de Minas Gerais - UFMG, Instituto de Ciências Agrárias, Insetário G.W.G. Moraes, Montes Claros, MG, Brasil
}

The highlands, in the Serra do Espinhaço, comprise the only "Globally Important Agricultural Heritage Systems" (GIAHS) in Brazil, a title granted by the United Nations Food and Agriculture Organization (FAO/UN) (Santos et al., 2021). Studies have been conducted in this GIAHS, especially to adapt new fruit species of high added value to production systems.

Physalis peruviana Linnaeus (Solanaceae) is a semi-shrub, erect, perennial plant in subtropical areas, native to the Andean region of South America (Fischer and AlmanzaMerchán, 1993). The production estimated per plant of this species is between $2-3 \mathrm{~kg}$ with a cycle lasting up to eight months (Lima et al., 2012; Aparecido et al., 2019). The fruits of $P$. peruviana are marketed fresh or processed and anti-tumor, anti-diabetic and anti-inflammatory activities are associated with their consumption (Dkhil et al., 2014; Hjartåker et al., 2015). In addition, P. peruviana is valued for its high antioxidant power and phenolic content (Dag et al., 2017).

Colombia and South Africa are the main world producers of $P$. peruviana, but this plant is also cultivated in Egypt, Ecuador, Peru, Kenya and Zimbabwe (Afsah, 2015; Bazalar Pereda et al., 2019). In Brazil, the cultivation of P. peruviana started in 1999 in the state of São Paulo and expanded to regions of altitude in the states of Santa Catarina and Rio Grande do Sul. This plant is cultivated mainly by small and medium producers providing a new type of edible fruit in the country (Muniz et al., 2014; Fariña et al., 2019). A large portion of the harvest is for domestic consumption, but it is also exported to Colombia (Salazar et al., 2008; Osorio Mora et al., 2016). The climatic conditions of the Brazilian highlands favor the cultivation of $P$. peruviana, but pests of this plant need to be studied in this region (Soares et al., 2014).

The objective of this work was to describe, for the first time, the occurrence of a species of Edessa (Hemiptera: Pentatomidae) feeding and reproducing on $P$. peruviana plants.
Adults, postures and immatures of a species of the genus Edessa (Figure 1) were observed between October and December 2019 and 2020, feeding on P. peruviana plants grown in an experimental area of the Universidade Federal dos Vales do Jequitinhonha e Mucuri (UFVJM) in the municipality of Diamantina, state of Minas Gerais, Brazil ( $18^{\circ} 12^{\prime}$ S; $43^{\circ} 34^{\prime} \mathrm{W}$; 1,387 masl). The climate of this region is Cwb - dry winter subtropical highland (Köppen, 1936).

Edessa adults were collected, preserved in 70\% alcohol in glass vials, assembled with entomological pins and sent to Dr. José Antônio Marin Fernandes of the Biology Department at the Universidade Federal do Pará (UFPA) in Belém, state of Pará, Brazil, who identified them as Edessa meditabunda (Fabricius, 1794) (Hemiptera: Pentatomidae). The insects used for identification were kept in the UFPA reference entomological collection.

Edessa meditabunda is the most studied species of this genus and originally from the Neotropical region (Husch et al., 2014). This stink bug feeds on photoassimilates of host plants, especially Glycine max L. (Szczerbowski et al., 2020), in addition to cultivated species of Fabaceae and Solanaceae, such as Phaseolus vulgaris L., Pisum sativum L., Solanum lycopersicum L. and Solanum tuberosum L. (Husch et al., 2014) and also feeds on the wild plant Physalis angulata L. (Krinski, 2013). The pest prefers vegetative structures (Panizzi and Lucini, 2019) but also damage pods causing dark lesions, which reduce plant productivity (Husch et al., 2014). The damage caused by E. meditabunda when uncontrolled can cause leaf retention and reduced germination and yield (Fonseca et al., 2017). Adults and nymphs of E. meditabunda fed on leaves and stems of $P$. peruviana. Postures of this insect were observed on this plant throughout the evaluation period (Figure 1).

Edessa meditabunda have potential to cause severe damages on the exotic fruit plant $P$. peruviana cultivated in Brazil. This insect should thus be included in programs of integrated pest management (IPM) for this crop.

*e-mail: marcusasoares@yahoo.com.br

Received: February 9, 2021 - Accepted: April 8, 2021 


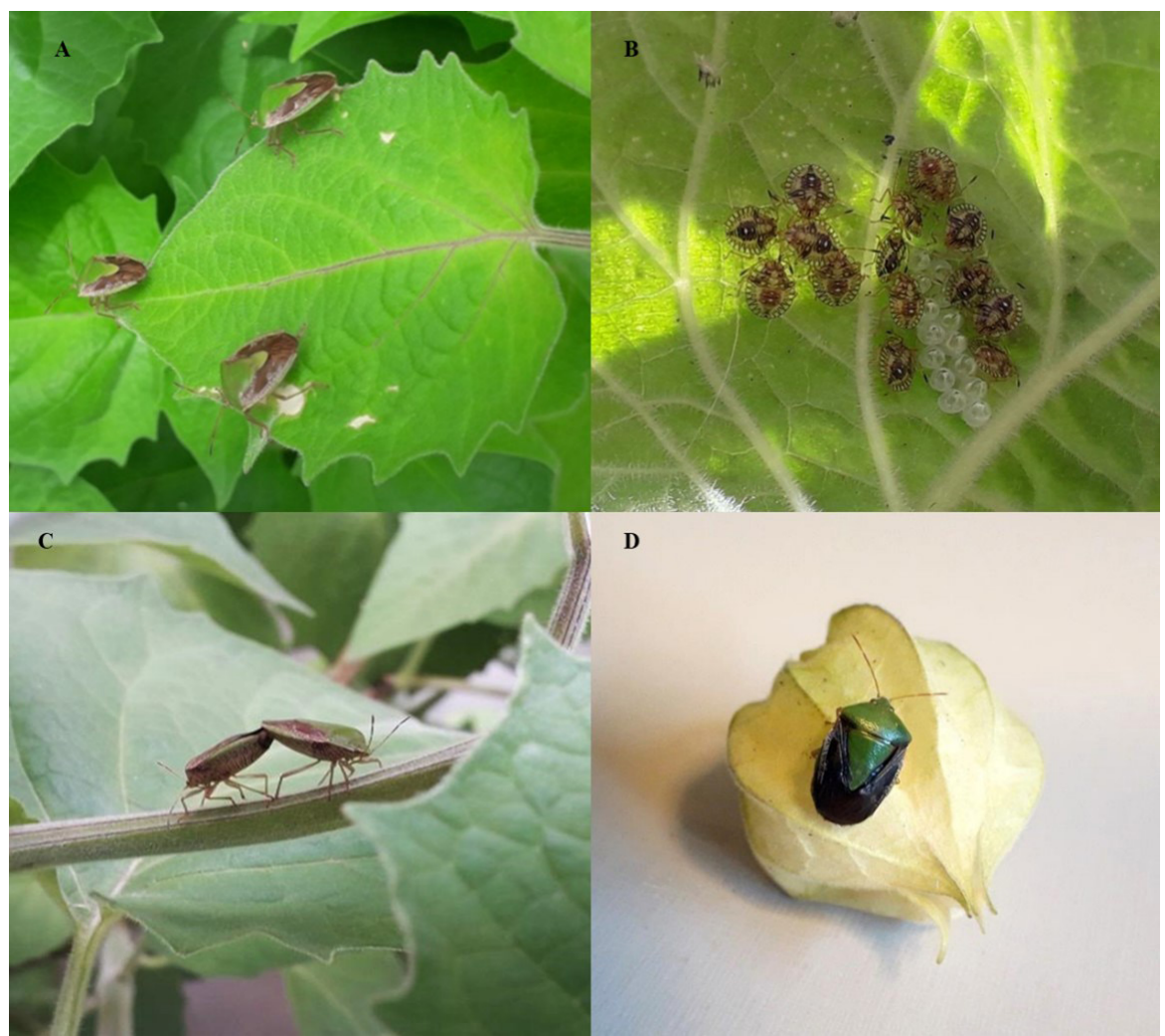

Figure 1. Edessa meditabunda (Hemiptera: Pentatomidae) adults on leaf (A), eggs and immature on leaf (B), adults on stems (C) and on fruit (D) of Physalis peruviana (Solanaceae) in Diamantina, Minas Gerais State, Brazil.

\section{Acknowledgements}

To the Brazilian institutions "Conselho Nacional de Desenvolvimento Científico e Tecnológico (CNPq)", "Coordenação de Aperfeiçoamento de Pessoal de Nível Superior (CAPES - Finance Code 001)", "Fundação de Amparo à Pesquisa do Estado de Minas Gerais (FAPEMIG)" and "Programa Cooperativo sobre Proteção Florestal (PROTEF) do Instituto de Pesquisas e Estudos Florestais (IPEF)" for financial support.

\section{References}

AFSAH, A.F.E., 2015. Survey of insects \& mite associated Cape gooseberry plants (Physalis peruviana L.) and impact of some selected safe materials against the main pests. Annals of Agricultural Science, vol. 60, no. 1, pp. 183-191. http://dx.doi. org/10.1016/j.aoas.2015.04.005.

APARECIDO, L.E.D.O., BATISTA, R.M., MORAES, J.R.D.S.C.D., COSTA, C.T.S. and MORAES-OLIVEIRA, A.F.D., 2019. Agricultural zoning of climate risk for Physalis peruviana cultivation in Southeastern Brazil. Pesquisa Agropecuária Brasileira, vol. 54, e00057. http:// dx.doi.org/10.1590/s1678-3921.pab2019.v54.00057.

BAZALAR PEREDA, M.S., NAZARENO, M.A. and VITURRO, C.I., 2019. Nutritional and antioxidant properties of Physalis peruviana L. fruits from the Argentinean northern Andean region. Plant Foods for Human Nutrition, vol. 74, no. 1, pp. 68-75. http://dx.doi. org/10.1007/s11130-018-0702-1. PMid:30471071.
DAG, D., KILERCIOGLU, M. and OZTOP, M.H., 2017. Physical and chemical characteristics of encapsulated goldenberry (Physalis peruviana L.) juice powder. Lebensmittel-Wissenschaft + Technologie, vol. 83, pp. 86-94. http://dx.doi.org/10.1016/j. lwt.2017.05.007.

DKHIL, M.A., AL-QURAISHY, S., DIAB, M.M., OTHMAN, M.S., AREF, A.M. and ABDEL MONEIM, A.E., 2014. The potential protective role of Physalis peruviana L. fruit in cadmium-induced hepatotoxicity and nephrotoxicity. Food and Chemical Toxicology, vol. 74, pp. 98-106. http://dx.doi.org/10.1016/j.fct.2014.09.013. PMid:25265456.

FARIÑA, A.E., GORAYEB, E.S., CAMELO-GARCÍA, V.M., BONIN, J., NAGATA, T., SILVA, J.M.F., BOGO, A., REZENDE, J.A.M., SILVA, F.N. and KITAJIMA, E.W., 2019. Molecular and biological characterization of a putative new sobemovirus infecting Physalis peruviana. Archives of Virology, vol. 164, no. 11, pp. 2805-2810. http://dx.doi.org/10.1007/s00705-019-04374-y. PMid:31451963.

FISCHER, G. and ALMANZA-MERCHÁN, P.J., 1993. La uchuva (Physalis peruviana $\mathrm{L}$.) una alternativa promisoria para las zonas altas de Colombia. Agricultura Tropical, vol. 30, pp. 79-87.

FONSECA, P.R.E.B., FERNANDES, M.G., JUSTINIANO, W., CAVADA, L.H., VIANA, C.A.L.T.P. and DA SILVA, J.A.N., 2017. Spatial distribution of adults and nymphs of stink bug, Edessa meditabunda (Fabricius, 1974) (Hemiptera: Pentatomidae) on soybean Bt and non-Bt. African Journal of Agricultural Research, vol. 12, no. 40, pp. 30133023. http://dx.doi.org/10.5897/AJAR2014.8723.

HJARTÅKER, A., KNUDSEN, M.D., TRETLI, S. and WEIDERPASS, E., 2015. Consumption of berries, fruits and vegetables and mortality among 10,000 Norwegian men followed for four 
decades. European Journal of Nutrition, vol. 54, no. 4, pp. 599-608. http://dx.doi.org/10.1007/s00394-014-0741-9. PMid:25087093.

HUSCH, P.E., DE OLIVEIRA, M.C.N. and SOSA-GÓMEZ, D.R., 2014 Characterization of injury caused by Edessa meditabunda (F.), Chinavia impicticornis (Stal), and Piezodorus guildinii (West.) (Hemiptera: Pentatomidae) to soybean. Neotropical Entomology, vol. 43, no. 3, pp. 276-281. http://dx.doi.org/10.1007/s13744014-0209-х. PMid:27193624.

KÖPPEN, W., 1936. Das geographische system der klimate. In: W. KÖPPEN and R. GEIGER, eds. Handbuch der Klimatologie. Berlin: Gebrüder Bornträger, pp. 1-44.

KRINSKI, D., 2013. Physalis angulata L. (Solanaceae): a potential host-plant of stink bugs Edessa meditabunda F. (Hemiptera, Pentatomidae). Biota Neotropica, vol. 13, no. 2, pp. 336-339. http://dx.doi.org/10.1590/S1676-06032013000200036.

LIMA, C.S.M., GALARÇA, S.P., BETEMPS, D.L., RUFATO, A.D.R. and RUFATO, L., 2012. Avaliação física, química e fitoquímica de frutos de Physalis, ao longo do período de colheita. Revista Brasileira de Fruticultura, vol. 34, no. 4, pp. 1004-1012. http:// dx.doi.org/10.1590/S0100-29452012000400006.

MUNIZ, J., KRETZSCHMAR, A.A., RUFATO, L., PELIZZA, T.R., RUFATO, A.D.R. and MACEDO, T.A.D., 2014. General aspects of physalis cultivation. Ciência Rural, vol. 44, no. 6, pp. 964-970. http:// dx.doi.org/10.1590/S0103-84782014005000006.

OSORIO MORA, O., LÓPEZ ENRIQUEZ, D.F., CUATIN RUANO, L.Y. and ANDRADE, J.C., 2016. Evaluación de un recubrimiento comestible a base de proteínas de lactosuero y cera de abeja sobre la calidad fisicoquímica de uchuva (Physalis peruviana L.). Acta Agronomica, vol. 65, no. 4, pp. 326-333. http://dx.doi. org/10.15446/acag.v65n4.50191.

PANIZZI, A.R. and LUCINI, T., 2019. Body position of the stink bug Dichelops melacanthus (Dallas) during feeding from stems of maize seedlings. Brazilian Journal of Biology = Revista Brasileira de Biologia, vol. 79, no. 2, pp. 304-310. http://dx.doi. org/10.1590/1519-6984.18250. PMid:30133556.

SALAZAR, M.R., JONES, J.W., CHAVES, B. and COOMAN, A., 2008. A model for the potential production and dry matter distribution of Cape gooseberry (Physalis peruviana L.). Scientia Horticulturae, vol. 115, no. 2, pp. 142-148. http://dx.doi.org/10.1016/j. scienta.2007.08.015.

SANTOS, J.B., SOARES, M.A. and MUCIDA, D.P., 2021. COVID-19 interferes in the disclosure of the first Brazilian GIAHS site. Brazilian Journal of Biology $=$ Revista Brasileira de Biologia, vol. 81, no. 4, pp. 1132. http://dx.doi.org/10.1590/1519-6984.241989.

SOARES, M.A., PEREIRA, S.L., GODANO, M., CASTRO, B.M.C., REIS, T.C., MOREIRA, R.A. and CRUZ, M.C.M., 2014. Lesiones de Tetranychus ludeni (Tetranychidae) en el cultivo de Physalis peruviana (Solanaceae) en Diamantina, Brasil. Revista Colombiana de Entomologia, vol. 40, no. 2, pp. 187-189.

SZCZERBOWSKI, D., SCHULZ, S. and ZARBIN, P.H.G., 2020. Total synthesis of four stereoisomers of methyl 4,8 , 12-trimethylpentadecanoate, a major component of the sex pheromone of the stink bug Edessa meditabunda. Organic $\mathcal{E}$ Biomolecular Chemistry, vol. 18, no. 26, pp. 5034-5044. http:// dx.doi.org/10.1039/D0OB00862A. PMid:32573631. 